\title{
The Nature of the Interactions between Flocculent Cells in the Flocculation of Saccharomyces cerevisiae
}

\author{
By P. J. MILL \\ Research Laboratory, Arthur Guinness Son and Co. \\ (Park Royal) Ltd., London, N.W. 10
}

(Received 20 September 1963)

\begin{abstract}
SUMMARY
The flocculation of a strain of brewers' yeast was absolutely dependent upon the presence of calcium; a concentration of $200 \mathrm{mM}-\mathrm{CaCl}_{2}$ was sufficient to ensure almost complete flocculation. No other metal could replace calcium; several metals aggregated potentially flocculent cells but also aggregated non-flocculent cells. Sodium ions antagonized the action of the calcium. The effects of $\mathrm{pH}$ value and esterification suggested that carboxyl groups were involved. The flocs had a 'melting temperature' of 50-60 ${ }^{\circ}$ and were dispersed by urea, suggesting that hydrogen bonds were also present.

Non-flocculent yeast was aggregated when the dielectric constant of the medium was decreased by the addition of organic solvents, but this aggregation was also dependent on the presence of traces of calcium. Conversely, increase of the dielectric constant of the medium, by adding formamide, dispersed flocculent yeast. Certain specific sugars also dispersed flocculent yeast. It is suggested that flocculent yeast cells are linked by salt bridges formed by calcium atoms joined with two carboxyl groups in the surfaces of different cells and that this structure is stabilized by hydrogen bonds formed between complementary patterns of carbohydrate hydrogens and hydroxyls in the cell surfaces.
\end{abstract}

\section{INTRODUCTION}

The phenomenon of yeast flocculation may conveniently be separated into fields of study comprising: the inherent tendency of a yeast to flocculate, the nature of the change from a non-flocculent to a potentially flocculent cell, and the interactions of potentially flocculent cells to form flocs (Mill, 1964). Several theories have been advanced to explain the formation of flocs (St Johnston, 1949; Hartong, 1951; Trolle, 1950; Masschelein \& Devreux, 1957), but none of them gives a completely satisfactory explanation of the phenomenon. The present paper describes experiments designed to elucidate the physico-chemical nature of the forces which bind flocculent cells together. Both ionic and hydrogen bonds seem to be involved. It is suggested that the flocculent yeast cells interact to form a calcium chelate complex.

\section{METHODS}

The strain of brewers' yeast, the media and the method of measuring flocculence have been described (Mill, 1964).

In many cases, where the flocculation had to be gauged in other than aqueous media, simple visual observations were used, the degree of flocculence being graded 
from 0 (completely dispersed) through,,,, \pm++++++++++ to +++++ (very highly flocculent).

Inorganic salts. When possible, AnalaR grade salts were used, but because of the extreme sensitivity of the test system to calcium, it was occasionally found necessary to purify these further. Recourse was made to normal inorganic chemical techniques such as recrystallization from water, but organic solvents were used with some salts of transition elements. Ferrous sulphate was obtained free from ferric sulphate by adding $70 \%(\mathrm{v} / \mathrm{v})$ ethanol to an aqueous solution of the commercial material. The ferrous salt precipitated and was thoroughly washed with ethanol and used at once.

Water. In experiments with solutions containing low calcium concentrations, it was found necessary to use double-distilled water which was passed through a mixed bed of cationic and anionic exchange resins immediately before use.

Glassware. For experiments involving low calcium concentrations, the glassware was cleaned in aqua regia overnight, rinsed well in de-ionized water and used immediately.

Calcium chloride + sodium acetate buffer. This was prepared by adding $0 \cdot 1 \%(\mathrm{w} / \mathrm{v})$ of calcium chloride to $0.05 \mathrm{M}$-sodium acetate + acetic acid buffer ( $\mathrm{pH} 4 \cdot 6$ ).

Yeast. Saccharomyces cerevisiae strain 7002 was used throughout and was grown in shaken cultures in glucose yeast extract salts ammonium medium (GYSA; Mill, 1964). Incubation was continued for $16 \mathrm{hr}$ to give non-flocculent yeast and for $40 \mathrm{hr}$ to give flocculent yeast.

Dispersed, potentially flocculent yeast was obtained by washing flocculent yeast three times in $1 \% \mathrm{NaCl}$ solution and then three times in de-ionized water.

\section{RESUL'TS}

Effect of washing flocculent yeast. It was very difficult to deflocculate yeast by washing with water as described by Jansen \& Mendlik (1951); a diminution but not a complete loss of flocculence was observed, unless the treatment was repeated many times. However deflocculation was readily achieved by washing the yeast with $1 \% \mathrm{NaCl}$ solution, and the yeast then remained dispersed when it was thoroughly washed with de-ionized water. It reflocculated immediately when a trace of calcium chloride was added to the suspension.

The concentration of calcium required to induce flocculence. Samples of dispersed potentially flocculent yeast were suspended in de-ionized water and various amounts of calcium chloride added. Figure $1 a$ shows that the yeast expressed almost its maximum flocculence at a calcium concentration of about $200 \mu \mathrm{M}$.

The effect of sodium and potassium ions. The experiment described above was repeated in the presence of $\mathrm{M}-\mathrm{NaCl}$ (Fig. $1 b$ ) or $\mathrm{M}-\mathrm{KCl}$ (Fig. $1 c$ ). The $\mathrm{NaCl}$ antagonized the action of the $\mathrm{CaCl}_{2}$ so that higher concentrations of the latter were needed to attain any given flocculence; $\mathrm{KCl}$ had little effect. This result is in accordance with the dispersal of flocculent yeast on washing with $\mathrm{NaCl}$.

The effect of some other metallic ions. In testing the action of metallic salts on potentially flocculent yeast, it is necessary to bear in mind that aggregation of cells as a response to the addition of an ion does not necessarily imply that that ion can replace the $\mathrm{Ca}^{2+}$ ion in the flocculation phenomenon; the other ion may aggregate the cells by some different mechanism. The criterion was therefore established that 
an ion was only to be considered as acting in the flocculation system when it aggregated potentially flocculent, but not non-flocculent, cells. Yeast samples were suspended in water at a concentration equivalent to about $4 \mathrm{mg}$. dry wt. yeast $/ \mathrm{ml}$., and small volumes of solutions of metallic salts were added to give final concentrations of 2 mM. Table 1 shows the degree of flocculence obtained (measured as log SR; see Mill, 1964). Only $\mathrm{Ca}^{2+}$ flocculated dispersed potentially flocculent yeast cells, but not non-flocculent cells; whereas $\mathrm{Fe}^{3+}, \mathrm{Sn}^{2+}, \mathrm{Ag}^{+}, \mathrm{Y}^{2+}, \mathrm{UO}_{2}{ }^{2+}, \mathrm{Ce}^{2+}$, and $\mathrm{Ti}^{2+}$ aggregated both types of cells. These aggregates differed in appearance from those obtained with $\mathrm{Ca}^{2+}$; in particular $\mathrm{Ag}^{+}$caused the cells to darken in colour and it was possible to see a deposit of black material around the cells when they were observed under the microscope. Feeble reactions with potentially flocculent cells were at first encountered with several salts, but disappeared when rigorous precautions were taken to eliminate traces of calcium.

\section{Table 1. Flocculence of yeast cells in the presence of metal ions}

Washed, potentially flocculent and non-flocculent cells were suspended in $2 \mathrm{~mm}$ solutions of the salts shown and the flocculence was measured. The flocculence is expressed as $\log \mathrm{SR}(\log \mu \mathrm{g}$. equivalent dry wt. yeast $/ \mathrm{ml} . / \mathrm{min}$.).

\begin{tabular}{|c|c|c|c|c|c|}
\hline & $\begin{array}{c}\text { Potentially } \\
\text { flocculent } \\
\text { cells } \\
\text { Log }\end{array}$ & $\begin{array}{l}\text { Non- } \\
\text { flocculent } \\
\text { cells } \\
\text { SR }\end{array}$ & \multirow{2}{*}{ Salt } & $\begin{array}{c}\text { Potentially } \\
\text { flocculent } \\
\text { cells } \\
\text { Log }\end{array}$ & $\begin{array}{l}\text { Non- } \\
\text { flocculent } \\
\text { cells } \\
\text { SR }\end{array}$ \\
\hline Salt & 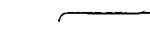 & 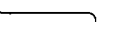 & & & \\
\hline $\mathrm{CaCl}_{2}$ & $4 \cdot 1$ & $1 \cdot 0$ & $\mathrm{MnCl}_{2}$ & $1 \cdot 7$ & $1 \cdot 0$ \\
\hline $\mathrm{FeCl}_{3}$ & $3 \cdot 4$ & $\mathbf{3 \cdot 5}$ & $\mathrm{FeSO}_{4}$ & $1 \cdot 7$ & $1 \cdot 0$ \\
\hline $\mathrm{YCl}_{3}$ & $4 \cdot 2$ & $4 \cdot 2$ & $\mathrm{Co}\left(\mathrm{NO}_{3}\right)_{2}$ & $1 \cdot 7$ & $1 \cdot 0$ \\
\hline $\mathrm{SnCl}_{2}$ & $4 \cdot 0$ & $4 \cdot 0$ & $\mathrm{NiCl}_{2}$ & $1 \cdot 5$ & $1 \cdot 0$ \\
\hline $\mathrm{TiCl}_{3}$ & $3 \cdot 7$ & $4 \cdot 1$ & $\mathrm{CuSO}_{4}$ & $1 \cdot 5$ & $1 \cdot 0$ \\
\hline $\mathrm{CeCl}_{3}$ & $3 \cdot 9$ & $4 \cdot 1$ & $\mathrm{ZnSO}_{4}$ & 1.7 & $1 \cdot 0$ \\
\hline $\mathrm{UO}_{2}\left(\mathrm{C}_{2} \mathrm{H}_{3} \mathrm{O}_{2}\right)_{2}$ & $2 \cdot 0$ & $1 \cdot 9$ & $\mathrm{SrCl}_{2}$ & $1 \cdot 4$ & $1 \cdot 0$ \\
\hline $\mathrm{AgNO}_{3}$ & $3 \cdot 4$ & $3 \cdot 3$ & $\mathrm{CdSO}_{4}$ & $1 \cdot 7$ & $1 \cdot 0$ \\
\hline $\mathrm{BeSO}_{4}$ & $1 \cdot 7$ & $1 \cdot 0$ & $\mathrm{BaCl}_{2}$ & $1 \cdot 7$ & $1 \cdot 0$ \\
\hline $\mathrm{MgSO}_{4}$ & $1 \cdot 7$ & $1 \cdot 0$ & $\mathrm{HgCl}_{2}$ & $1 \cdot 7$ & $1 \cdot 0$ \\
\hline $\mathrm{Al}_{2}\left(\mathrm{C}_{4} \mathrm{H}_{4} \mathrm{O}_{6}\right)_{3}$ & $1 \cdot 7$ & $1 \cdot 0$ & $\mathbf{P d C l}_{2}$ & $1 \cdot 7$ & $1 \cdot 0$ \\
\hline $\mathrm{CrCl}_{3}$ & $1 \cdot 7$ & $1 \cdot 0$ & & & \\
\hline
\end{tabular}

The effect of $\mathrm{pH}$ value. A range of $0.05 \mathrm{M}$-acetate or glycine buffers was prepared and $\mathrm{CaCl}_{2}$ was added to them to give a final concentration of $5 \mathrm{~mm}$. Samples of potentially flocculent yeast were suspended in these mixtures at a final concentration equivalent to about $4 \mathrm{mg}$. dry wt./ml. and the flocculence of the suspensions was measured (Fig. 2). The flocculence was low at $\mathrm{pH} 2$ but rose with increasing $\mathrm{pH}$ and reached a maximum between $\mathrm{pH} 4 \cdot 5$ and $\mathbf{5} \cdot \mathbf{5}$.

Esterification. When potentially flocculent yeast was shaken overnight in $0.05 \mathrm{M}$ acetate buffer ( $\mathrm{pH} 4 \cdot 0$ ) containing $5 \%$ 1,2-epoxypropane, it became completely non-flocculent. When ethylene glycol was substituted for the epoxypropane, little change in potential flocculence occurred.

The effect of temperature. A suspension of flocculent yeast in calcium chloride + sodium acetate buffer was placed in a thin-walled tube dipping into a large bath of water. Both the water and the yeast were thoroughly stirred whilst the water was gently heated. The flocculence of the yeast was graded by eye at intervals and at the same moment the temperature of the suspension was measured with a thermo- 
meter which dipped into it. Table 2 shows that there was at first a slight decrease in flocculence as the temperature was increased and that a rapid change occurred between $50^{\circ}$ and $60^{\circ}$. At $60^{\circ}$ the yeast was virtually completely dispersed. As the temperature was lowered again, the flocculence reappeared.

The effect of urea. Samples of flocculent yeast were suspended in portions of the calcium chloride + sodium acetate buffer to which different amounts of urea had been added. The yeast was completely dispersed at a urea concentration of $40 \%$, but when the urea was removed by washing the yeast with buffer, the flocs reappeared.

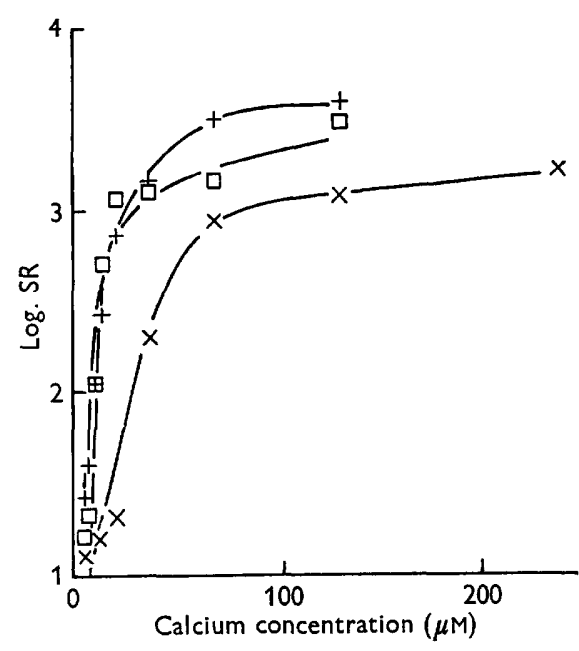

Fig. 1

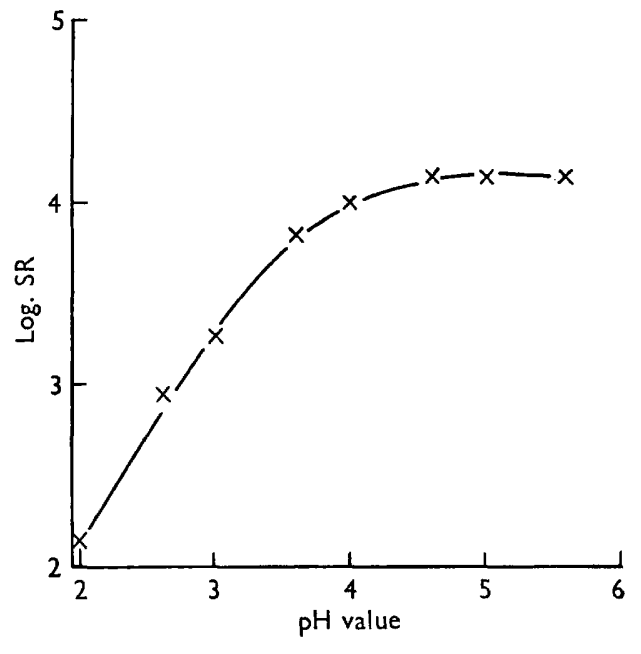

Fig. 2

Fig. 1. Dependence of flocculence on calcium concentration with potentially flocculent cells of Saccharomyces cerevisiae suspended in $(a)$ water, $+-+;(b) \mathrm{M}-\mathrm{NaCl}, \times-\times ;(c) \mathrm{M}-\mathrm{KCl}$, $\square-\square$. , Flocculence is given as $\log \mathbf{S R}=\log \mu \mathrm{g}$. equivalent dry wt. of cells $/ \mathrm{ml} . / \mathrm{min}$.

Fig. 2. The flocculence of potentially flocculent cells of Saccharomyces cerevisiae suspended in media at various $\mathrm{pH}$ values. Flocculence is given as $\log \mathrm{SR}=\log \mu \mathrm{g}$. equivalent dry wt. of cells $/ \mathrm{ml}$./min.

Table 2. The effect of temperature on flocculence of yeast cells

Flocculent cells suspended in sodium acetate + calcium chloride buffer were gently heated and their flocculence was graded by eye at different temperatures. Temperature

$\begin{array}{lc}\left({ }^{\circ}\right) & \text { Flocculence } \\ \mathbf{2 3} & +++++ \\ \mathbf{4 5} & +++++ \\ \mathbf{4 7} & ++++ \\ \mathbf{5 0} & +++\end{array}$

\section{Temperature}

51

54
58

62
Flocculence

++
+
\pm
-

The effect of organic solvents. There was no effect when organic solvents were added to flocculent yeast or to non-flocculent yeast which had been washed in saline. However, when organic solvents were added to suspensions of non-flocculent yeast in the presence of traces of calcium chloride, flocculation occurred. On removing the solvent the yeast dispersed once more.

Methanol, ethanol, propanol, acetone and dioxane were each effective when used 
Table 3. Aggregation of non-flocculent yeast by organic solvents

Organic solvents were added to suspension of non-flocculent yeast in $2 \mathrm{~mm}-\mathrm{CaCl}_{2}$ and the flocculence of the suspension was graded by eye.

\begin{tabular}{|c|c|c|}
\hline $\begin{array}{c}\text { Solvent } \\
\text { concentration } \\
(\%, v / v)\end{array}$ & $\begin{array}{l}\text { Apparent } \\
\text { dielectric } \\
\text { constant }\end{array}$ & Flocculence \\
\hline \multicolumn{3}{|c|}{ Methanol } \\
\hline 29 & 74 & - \\
\hline 38 & 71 & + \\
\hline 41 & 70 & ++ \\
\hline 48 & 68 & ++++ \\
\hline 52 & 66 & $+t+t$ \\
\hline \multicolumn{3}{|c|}{ Ethanol } \\
\hline 23 & 76 & - \\
\hline 29 & 75 & + \\
\hline 33 & 73 & ++ \\
\hline 41 & 70 & $++t+$ \\
\hline 44 & 69 & ++++ \\
\hline \multicolumn{3}{|c|}{ isoPropanol } \\
\hline 23 & 74 & - \\
\hline 29 & 73 & + \\
\hline $\mathbf{3 3}$ & 71 & ++ \\
\hline 41 & 67 & $+t+t$ \\
\hline 44 & 64 & $++t+$ \\
\hline \multicolumn{3}{|c|}{ Acetone } \\
\hline 23 & 75 & - \\
\hline 29 & 74 & $+t$ \\
\hline 31 & 71 & ++++ \\
\hline 38 & 69 & ++++ \\
\hline \multicolumn{3}{|c|}{ Dioxane } \\
\hline 9 & 76 & - \\
\hline 17 & 73 & ++ \\
\hline 23 & 68 & $+t+t$ \\
\hline 29 & 66 & $+t+t$ \\
\hline
\end{tabular}

Table 4. Dispersal of flocculent yeast by sugars

\begin{tabular}{|c|c|c|c|c|c|c|}
\hline \multirow{3}{*}{ Sugar } & \multicolumn{6}{|c|}{ Sugar concentration (\%) } \\
\hline & 0 & 5 & 10 & 15 & 20 & 30 \\
\hline & \multicolumn{6}{|c|}{ Flocculence (graded by eye) } \\
\hline $\begin{array}{l}\text { Glucose } \\
\text { Mannose } \\
\text { Galactose } \\
\text { Fructose }\end{array}$ & $\begin{array}{l}+++++ \\
+++++ \\
+++++ \\
+++++\end{array}$ & $\begin{array}{c}+++ \\
+ \\
++++ \\
+++++\end{array}$ & $\begin{array}{c}+ \\
+ \\
+++ \\
++++\end{array}$ & $\begin{array}{c}t \\
+ \\
+++ \\
++++\end{array}$ & $\begin{array}{c}- \\
- \\
+++ \\
+++\end{array}$ & $\begin{array}{c}- \\
- \\
++ \\
++\end{array}$ \\
\hline $\begin{array}{l}\text { Maltose } \\
\text { Sucrose } \\
\text { Lactose }\end{array}$ & $\begin{array}{l}+++++ \\
+++++ \\
+++++\end{array}$ & $\begin{array}{c}++ \\
+ \\
+++\end{array}$ & $\begin{array}{c}+ \\
+ \\
+++\end{array}$ & $\begin{array}{c}+ \\
- \\
++t\end{array}$ & $\begin{array}{c}+ \\
+ \\
++\end{array}$ & $\begin{array}{l}+ \\
+ \\
+\end{array}$ \\
\hline $\begin{array}{l}\text { Mannitol } \\
\text { Glucosamine }\end{array}$ & $\begin{array}{l}+++++ \\
+++++\end{array}$ & $\begin{array}{c}+++++ \\
++++\end{array}$ & $\begin{array}{l}++++ \\
++++\end{array}$ & $+\dot{t}+$ & + & $\dot{+}$ \\
\hline
\end{tabular}

. = not tested. 
in concentrations such that the mixture had a dielectric constant approaching 68 (Table 3). (This value is an apparent one obtained from published tables; it takes no account of the contribution of the electrolyte, but this will be approximately the same in each case.)

The effect of sugars. The finding by Eddy (1955 a) that certain specific sugars could disperse flocculent yeast was confirmed. The sugars were tested by dissolving them, at various concentrations, in calcium chloride + sodium acetate buffer, and suspending washed potentially flocculent yeast in these mixtures at a final concentration equivalent to about $4 \mathrm{mg}$. dry wt. $/ \mathrm{ml}$. The flocculence was graded by eye (Table 4).

The effect of formamide. The ability of formamide to disperse flocculent yeast was tested in a similar manner. Samples of flocculent yeast suspended in $\mathrm{mu}-\mathrm{CaCl}_{2}$ were dispersed by $4 \%$ formamide. This effect was however dependent upon the electrolytes present; in a solution $0 \cdot 1 \mathrm{M}$ with respect to $\mathrm{NaCl}$ or $\mathrm{KCl}$ and $\mathrm{mM}$ with respect to $\mathrm{CaCl}_{2}, 20 \%$ formamide did not disperse flocculent yeast.

\section{DISCUSSION}

The work described here is concerned with elucidating the nature and location o the forces which bind together the flocculent yeast cells; it does not consider the changes which convert a non-flocculent yeast to a flocculent one. A single strain of yeast was used throughout to minimize variations due to differences in the structure of the yeast. Similarly, the control for the flocculent yeast was sought in the non-flocculent stage of the same strain, rather than in a different non-flocculating strain.

That calcium is an essential requirement for flocculation was one of the earliest known features of the phenomenon. It has been claimed that a number of different metallic ions can replace calcium (Jansen \& Mendlik, 1953; Lindquist, 1953; Eddy, $1955 b$ ), but it was not possible to confirm this. Provided that the reagents employed were free of calcium, only a few other metals aggregated the yeast cells used, and every one of these also aggregated non-flocculent yeast cells. Thus there seems to be no evidence that these other ions act in the same manner as calcium or combine with the same groups in the cell surface. Silver ions apparently acted by depositing metallic silver on the cell surfaces, but it is noteworthy that all the other ions which were effective were polyvalent. The case of iron is particularly striking in that $\mathrm{Fe}^{3+}$ caused an intense aggregation but $\mathrm{Fe}^{2+}$ ions were inactive. Since, of all the ions tested, only calcium appeared to act in the normal flocculation mechanism, it must be supposed that strict steric relationships exist between the yeast cells and the ions in the flocculent state.

That sodium antagonizes the action of calcium suggests that the latter normally combines with the cell wall at some definite site from which it can be competitively displaced. Sodium might be expected to act in such a system since its crystal ionic radius $(0.98 \AA)$ is very near that of calcium $(0.99 \AA)$.

Two roles can be envisaged for calcium: (i) it might sterically block a group in the cell surface whose presence maintained the non-flocculent state; (ii) it might form a 'salt bridge' between two yeast cells, i.e. its two valencies might enable it to form a bond between a combining site on each of two different cells (Harris, 1959). Of these two roles, the former should be equally well performed by univalent sodium 
whereas the latter role could not. Since sodium reacts with the combining site and in doing so deflocculates the yeast, the evidence favours the salt bridge hypothesis. This does not exclude the possibility that the action of calcium is in part due to the blocking of charged groups in the cell surface.

Groups which might exist in the cell surface, and be capable of combining with calcium at pH 4.6, comprise carboxyl, phosphate and sulphate. The effect of $\mathrm{pH}$ value on flocculation indicates that the phenomenon is dependent upon the ionization of a group of $\mathrm{pK}$ about 4, suggesting that carboxyl groups are involved. This is supported by the effect of esterification: under the conditions used, epoxypropane preferentially combines with carboxyl groups to form propylene glycol esters (Fraenkel-Conrat, 1944). The objection might be raised that the action of the epoxypropane was due to its solvent and toxic properties, but ethylene glycol, which should have similar properties, did not destroy potential flocculence and of course did not form esters under these conditions. There is thus some evidence that carboxyl groups are involved in flocculation, but there is as yet no direct evidence that these groups are so involved as combining sites for calcium ion.

A salt bond between calcium and a carboxyl group would normally be largely ionic in character and dissociated at $\mathrm{pH} 4 \cdot 6$, so that some further type of bonding must be sought to account for flocculence. The effect of temperature on the flocs is in fact an indication that weak secondary, almost certainly hydrogen, bonds are present. The flocs show a 'melting temperature' of 50-60'. This accords well with values found for the helices of collagen (Verzar, 1963) and nucleic acids (Doty, 1962); these helices are maintained by hydrogen-bonding. The lack of sharpness in the 'melting' may simply result from the method used, but it is also in accord with the picture, here developed, of a mutual stabilization of salt and hydrogen bonds. The deflocculation of the yeast by urea also supports the view that hydrogen bonds are involved. Since the cells regain their potential flocculence immediately the urea is removed, it is not to be supposed that this acts by disrupting structures in the cell surface, but rather merely by interfering with the interactions between cells.

At first sight the action of organic solvents in promoting aggregation of nonflocculent yeast cells might be dismissed as unconnected with the true flocculation phenomenon were it not for the requirement for calcium. This dependence on the presence of calcium strongly suggests that the aggregation of the yeast cells is in fact a manifestation of the flocculation phenomenon. The organic solvents most probably exert their action by decreasing the dielectric constant of the solution, for the aggregation occurs at about the same value of dielectric constant with each solvent. A decrease in the value of the constant will have two effects: it will increase the strength of hydrogen bonds and it will diminish the ionization of salt bonds, i.e. it will increase their strength also. Both types of bonding envisaged here will thus be intensified. Any groups in the yeast cell surface, which are charged by ionization, will tend to become reassociated and hence discharged when the dielectric constant is decreased; but the aggregation of the cells may not be exclusively ascribed to this, in view of the calcium requirement. The reverse process is seen in the dispersal of flocculent cells when the dielectric constant of the medium is increased by adding formamide.

A clue to an origin of the postulated hydrogen bonds was provided by the observation that certain specific sugars would dissociate flocs at relatively low concentra- 
tions (Eddy, 1955a). In agreement with this author, it was found that of the four naturally occurring hexoses, only glucose and mannose showed a high dispersing activity. Sucrose and maltose were also effective, but lactose much less active. Modifications of the structures of the hexoses, as in mannitol and glucosamine, resulted in a loss in activity. Glucose and mannose are the dominant sugar residues of the yeast cell wall (Northcote \& Horne, 1952), which suggests that the hydrogenbonding involves complementary patterns of carbohydrate hydroxyls and hydrogens in the wall surface.

The general picture which emerges from these considerations is of a calcium atom forming a bridge between receptor sites on two different yeast cells; and these receptors may possibly be carboxyl groups. The bonds involved are at first essentially ionic, but once established the cells will transitorily approach closely to one another and hydrogen bonding will be set up between complementary carbohydrate structures in the walls of the two cells. The resulting complex will thus assume a chelate character, with the calcium-complexing groups held in a definite spatial relationship to each other.

I am grateful to the Directors of Arthur Guinness Son and Company for permission to publish this work. I thank Sir Cyril Hinshelwood, F.R.S., and Dr T. C. N. Carroll for helpful discussions, and Mr R. W. Selous for technical assistance.

\section{REFERENCES}

Doty, P. (1962). The relation of the interaction of polynucleotides to the secondary structure of nucleic acids. In 'The Structure and Biosynthesis of Macromolecules'. Biochem. Soc. Symp. 21, 8.

Edoy, A. A. $(1955 a)$. Flocculation characteristics of yeasts. II. Sugars as dispersing agents. J. Inst. Brew. 61, 313.

EDDy, A. A. $(1955 b)$. Flocculation characteristics of yeasts. III. General role of floceulating agents and special characteristics of a yeast flocculated by alcohol. J. Inst. Breze. $61,318$.

Fraenkel-Conrat, H. (1944). Action of 1,2-epoxides on proteins. J. biol. Chem. 154, 247.

Harris, J. O. (1959). Possible mechanism of yeast flocculation. J. Inst. Brew. 65, 5.

Hartong, B. D. (1951). Flocculation of yeast in breweries. Proc. European Brewery Convention Congr. Brighton, p. 10.

Jansen, H. E. \& Mendlik, F. (1951). A study on yeast flocculation. Proc. European Brewery Convention Congr. Brighton, p. 59.

Jansen, H. E. \& Mendlik, F. (1953). A study on yeast flocculation II. Proc. European Brewery Convention Congr. Nice, p. 143.

Lindquist, W. (1953). On the mechanism of yeast flocculation. J. Inst. Brere. 59, 59.

Masschelein, C. \& Devreux, A. (1957). Flocculence et structure de la paroi cellulaire de la levure. Proc. European Brewery Convention Congr. Copenhagen, p. 194.

MrLl, P. J. (1964). The effect of nitrogenous substances on the time of flocculation of Saccharomyces cerevisiae. J. gen. Microbiol. 35, 53.

Northcote, D. H. \& Horne, R. W. (1952). The chemical composition and structure of the yeast cell wall. Biochem. J. 51, 232.

St Johnston, J. H. (1949). The flocculation of proteins in wort and beer. Proc. European Brewery Convention Congr. Lucerne, p. 62.

Trolle, B. (1950). Experiments on bottom fermentation. III. The quantity of suspended yeast during fermentation as a function of carbon dioxide fermentation under different conditions. J. Inst. Brew. 56, 364.

Verzar, F. (1963). The aging of collagen. Sci. Amer. 208 (4), 104. 